\title{
Nutritional Evaluation of Brioche Bread Made from Egyptian Wheat and Enriched with Garden Cress Seeds (GCS) Powder as a Functional Food
}

\author{
Omaima M. Dewidar ${ }^{1 *}$ and Ghada M. El-Kherbawy ${ }^{2}$ \\ ${ }^{1}$ Department of Crops Technology, Food Technology Research Institute, Agricultural Research Center, Giza, Egypt \\ ${ }^{2}$ Home Economics Division, Food Science Department, Faculty of Agriculture, Cairo University, Egypt
}

Received: 7/4/2019

\begin{abstract}
The present study was conducted to explore the nutritive value of Garden Cress Seeds (GCS) and its utilization into products like brioche bread to improve its nutritional quality. Rheological characteristics of two Egyptian wheat flour varieties (Gemmeiza 9 and Seds 12) using Mixolab indices (Chopin+) were done to choice the suitable one for brioche dough. DPPH scavenging activity (\%) and total phenols of GCS were determined. Different levels of GCS powder (Zero, 1, 2, 3, 4 \& 5\%) were added to the chosen wheat flour and examined its impact on chemical composition (moisture, protein, fat, ash, fiber, $\mathrm{CHO}$ by difference \& calories). Sensory evaluation, physical properties (water activity, color \& freshness properties) and microbiological examination (total count, molds-yeast \& Staphylococcus aureus) for the product were done. Results showed that concerning rheological indices, Seds 12 variety had higher dough stability (4.02 min), higher water absorption (58.1\%), higher protein quality as $\mathrm{C}_{2}=(0.44 \mathrm{Nm})$ and higher quality of starch as $\mathrm{C}_{3}=(1.90 \mathrm{Nm})$. Also, showed the most stable gel in the hot phase $\left(\mathrm{C}_{4}=1.72 \mathrm{Nm}\right)$ and ordering of starch molecules $\left(\mathrm{C}_{5}\right)=2.67 \mathrm{Nm}$ when compared with Gemmeiza 9 which recorded (3.03 min, $\left.51.2 \%\right)$ and $(0.31,1.84,1.62$ and $2.45 \mathrm{Nm})$, respectively. Based on that, it was selected for dough preparation. Adding GCS powder in $1,2 \& 3 \%$ percentage to the dough showed good acceptability for brioche bread regarding sensory evaluation. No significant difference was observed either when either the previous concentrations were compared to each other or the control sample. GCS powder contains considerable amounts of protein, fat, ash, fiber and CHO which were 20.68, $26.79,4.25,4.25 \& 39.49 \mathrm{~g} / 100 \mathrm{~g}$, respectively. Also, it contains high amounts from minerals $(\mathrm{Fe}, \mathrm{Mn}, \mathrm{Zn}, \mathrm{Cu}, \mathrm{Ca}, \mathrm{Mg}$, $\mathrm{P}, \mathrm{K} \& \mathrm{Na}$ ). Basically, moisture, protein, fat, ash and minerals contents were increased directly proportional to the level of GCS added in the formulation of brioche. Moreover, brioche bread samples had $\mathrm{Ca} / \mathrm{P}$ ratio ranged from 1.63 to 1.92 and $\mathrm{Na} / \mathrm{K}$ ratio 0.04 which close to recommended ratios. It also good source of phenolic compounds, as it contains appreciable amounts from total phenols (44.49 mg/100g as Gallic acid) and its DPPH scavenging activity was $47.10 \%$. According to the microbiological examination, it recommended use high concentrations from GCS in brioche bread (4 and 5\%) as they showed antibacterial and antifungal attitude than the low concentrations (1, $2 \& 3 \%)$; the differences was significant $(p<0.05)$. The obtained results can use easily in the Egyptian Bakery pilot plants to arrive strategic goal of Egyptian government especially, the low cost of brioche bread unit as a functional food.
\end{abstract}

Keywords: Mixolab (Chopin + ), Brioche, Garden Cress Seeds, Seds 12 wheat, Rheological characteristics, Microbiological examination, Chemical analysis.

\section{INTRODUCTION}

Wheat is taking an important place among crops as staple food source; it considered the main section of nutrients to the most of world population as its grains can be ground into flour, semolina, etc. The wheat grain contains $2-3 \%$ germ, $13-17 \%$ bran and $80-85 \%$ mealy endosperm which form the basic ingredients of bread and other bakery products, as well as pastas like brioche, pizza etc. (Belderok et al., 2000; Sramkováa et $a l$. , 2009). Shewry and Hey (2015) also added that, wheat is the most widely grown cereal crop in the world and bread wheat represents a staple food for human nutrition.

Manufacture of bakery products shapes an ingrained part of food structure to ensure feeding of population. They shape deep-rooted part in ensuring the nourishment of the population as the volume of production stimulated by a larger supply of varieties which has been continuously growing as a result of development new kinds of products, availability for consumption, taste variety, and its ability for long-term storability (Hozova et al., 2002). Pertuzatti et al. (2015) stated that, consuming of bakery and pastry products increases day by day, also the demanding of consumers. So this sector becomes a competitive market for quality. However, Sabanis and Tzia (2009) reported that, the preparation of bread from wheat flour only is considered to be nutritionally poor. That is why Food Fortification Initiative (2019) admitted that, fortification is successful process because it makes frequently eaten foods more nutritious without relying on consumers to change their habits.

Thought, Rosell (2009) added that, bread brioche has an important contribution in a wellbalanced diet, due to its content on starch complex carbohydrates and protein. Alvarez-Jubete et al. (2010) also confirmed that, partial replacement of wheat flour with non-wheat flour such as garden cress seeds which are rich in protein, calcium, iron, and polyphenols resulted in brioche bread high in these nutrients, improves the nutritional quality of bakery products and satisfies consumers' demands for healthy food.

Tacer-Caba et al. (2015) stated that, essential understandings of formula, processes, and storage of the most public cereal-based foods, including brioche are important to obtain great-tasting, high-quality and storage-stability for these products and also meet the requirements of consumers in different parts of the 
world. The formulas of these products are often tailored and the processing methods are commonly adjusted to production different variety of products. Therefore, they recommended more research to improve their nutritional value and quality for human health advantage, that by develop using multigrain \& whole-grain flours in different products and adding antioxidants from natural sources, such as garden cress seeds to raise antioxidant content.

Gokavi et al. (2004) stated that, Garden cress seeds are an important medicinal crop in India while, it is natively grown in west of Asia and Egypt and belongs to the Brassicaceae family, which is rich in health promoting phytochemical constituents. The total phenolic compounds are one of the most important groups of natural antioxidants that are responsible for a high antioxidant capacity. Seeds of L. sativum are claimed to possess varied medicinal properties (Kasabe et al., 2012). Also it has health promoting properties which can be used as a functional food.

Meanwhile, Doke and Guha (2014) reported that, Garden cress seeds have strong antioxidant capacity which may be due to its content from phenolic compounds .Whereas GCS are good source of proteins, dietary fiber, minerals and essential amino acids.

In a study by Singh and Paswan (2017), physicochemical, chemical composition and medicinal properties were estimated, also development the food product with garden cress seeds. They found that, GCS had valuable functional properties and the products will develop by fortified with it.

The present investigation was carried out to determine the rheological, chemical and technological properties of two Egyptian wheat varieties flours and examine their performance in producing brioche bread supplemented with garden cress seeds powder.

\section{MATERIALS AND METHODS}

\section{Raw materials:}

Egyptian wheat varieties Gemmeiza 9 and Seds 12 were obtained from Crops Research Institute, Agriculture Research Center, Ministry of Agriculture, Giza, Egypt. Sugar, egg, milk, salt, oil, yeast, baking powder and Garden cress seeds were purchased from the local market at Giza, Egypt.

\section{Preparation of wheat flour and GCS powder:}

Wheat grain samples (Gemmeiza 9 and Seds 12) were separately cleaned, conditioned to $14 \%$ moisture content. Then milled by using fractionation Laboratory mill (Qudrumat Senior Laboratory Mill) according to AOAC (2012). To obtain the percentage extraction rates of two wheat varieties from their wheat flour $(75$ $\& 77 \%$ ), it sieved to pass through 60 mesh sieve and it used (wheat flour $72 \%$ extraction rate) to make dough of brioche bread.

Preparation of garden cress seeds powder by using grinder seed to convert it into the powder form. Sieving process with 60 mesh size used to sieve the end product GCS powdered.

\section{Mixo Lab:}

Rheological behaviour of wheat flour was investigated using Mixo lab (Chopin ${ }^{+}$, Tripette et Renaud, Paris, France) which simultaneously determines dough characteristics during the process of mixing at constant temperature, as well as during the period of constant heating and cooling (Ozturk et al., 2009).

Wheat flour (Seds 12, 72\%) was replaced by GCS powder at levels $1,2,3,4$ and $5 \%$ in brioche bread making.

\section{Brioche making:}

In order to select appropriate recipe for the present study, various recipes were explored and choose the suitable one. The product was developed with the incorporation of Garden cress seeds at five levels to make them more nutritious and healthy, plus the control sample (without garden cress seeds). The dried component mix together firstly, then the rest of the ingredients (liquids) added to the previous mixture and complete mixing until having the suitable texture to the dough. The dough was fermented before and after chopping in small parts. Baking oven was used for baking the prepared brioche at $180^{\circ} \mathrm{C}$ for $12-15$ minutes (Altamirano-Fortoul and Rosell, 2011).

\section{Nutritional value for the products:}

The nutritive value of the control and modified samples were computed using ICMR (2010), also compared with both control to study the extent of nutrient enrichment and Recommended Daily Allowance (RDA).

\section{Analytical Methods:}

Proximate analysis of raw materials and brioche bread samples (moisture, protein, fat, ash and crude fiber) were determined according to the methods described in AOAC (2012).

Total carbohydrates were calculated by difference.

Total calories were calculated as mentioned by Kerolles (1986) according to the following equation:

Total calories $=4$ (protein + Carbohydrates) +9 (fat). Minerals: $\mathrm{Fe}, \mathrm{Mn}, \mathrm{Zn}, \mathrm{Cu}, \mathrm{Ca}, \mathrm{Mg}, \mathrm{P}, \mathrm{K}$ and $\mathrm{Na}$ in control and prepared brioche samples were determined according to the method described in AOAC (2012).

Table (1): Chemical composition (\%) of wheat flour (Seds 12)

Parameter

Moisture

Protein

Fat

Ash

Wheat flour (Seds 12)

Crude fiber

Total Carbohydrates

$13.5 \pm 0.06$

$12.24 \pm 0.45$

$1.36 \pm 0.43$

$0.56 \pm 0.02$

$0.18 \pm 0.21$

* Mean \pm SD
$72.16 \pm 0.84$ 


\section{Brioche storage:}

Brioche samples were packed in poly ethylene packaging material at room temperature $\left(25 \pm 1^{\circ} \mathrm{C}\right)$ for 14 days.

\section{Total phenols and DPPH scavenging activity:}

Free radical scavenging activity was determined by 1, 1-diphenyl-2-picrylhydrazyl (DPPH) assay (Kasabe et al., 2012).

Radical scavenging activity was calculated using the following formula:

$$
\begin{aligned}
& \% \text { radical scavenging activity }= \\
& \frac{\text { Control O.D. }- \text { Sampl O.D. }}{\text { Control O.D. }} \times 100
\end{aligned}
$$

Total phenolics content was estimated by using Folin-Ciocalteau method with some modifications (Kasabe et al., 2012).

\section{Sensory evaluation:}

Sensory evaluation was conducted using a 15 untrained member and a 5-point hedonic rating scale, with $0=$ inconsumable, $1=$ unacceptable, $2=$ acceptable, $3=$ satisfactory, and $4=$ excellent (Pertuzatti et al., 2015; Smith and Jianmei, 2015; Massoud et al., 2016). The panelists evaluated their preference on five sensory attributes (color, aroma, texture, flavor and overall acceptability) of the product.

\section{Physical properties:}

Measurement of the crumb brioche color parameters were measured by using a Minolta colorimeter (Chroma Meter CR-400/410, Konica Minolta, Japan).

Water activity $\left(a_{\mathrm{w}}\right)$ of crumb samples was measured using an Aqua Lab Series 3 (Deca devices, Pullman, USA) at $22^{\circ} \mathrm{C}$ (Altamirano-Fortoul and Rosell, 2011).

Freshness of brioche bread was measured at room temperature during storage (zero, 24, 48 and $72 \mathrm{~h}$ ) by alkaline water retention capacity (AWRC) according to the method of Yamazaki (1953), Kitterman and Rubenthaler (1971).

\section{Microbiological evaluation:}

Total bacterial count (on standard plate count agar), Yeast \& Mold and Staphylococcus aureus were enumerated at room temperature $\left(25 \pm 1^{\circ} \mathrm{C}\right)$ according to the American Public Health Association Methods (APHA, 1994).

\section{Cost and Purchase intent:}

They were evaluated according to Risen and Risen (2008).

\section{Statistical analysis:}

Test of normality distribution was carried out according to Shapiro and Wilk (1965), by using SPSS v. 17.0 (2008) computer package. A randomized complete block design with two factors were used for analysis all data with three replications for each parameter. Estimates of LSD were calculated to test the significance of differences among means according to Snedecor and Cochran (1994) by used Assistant program.

\section{RESULTS AND DISCUSSION}

The extraction percentage for the two Egyptian wheat varieties (Gemmeiza 9 and Seds 12) was illustrated in Table (2).

Table (2): Extraction percentage of the two Egyptian wheat varieties

\begin{tabular}{lcc}
\hline Item & Gemmeiza 9 & Seds 12 \\
\hline Endosperm (\%) & 75 & 77 \\
Bran (\%) & 22 & 20 \\
Germ (\%) & 3 & 3 \\
\hline
\end{tabular}

From this Table it could be concluded that, the variety Gemmeiza 9 had lower percentage (75\%) from endosperm than Seds 12 (77\%). While, bran percentage was higher in Gemmeiza 9 (22\%) than Seds 12 (20\%). However, the germ percentage was record the same value $(3 \%)$ in the two varieties.

Table (3) showed the rheological parameters of the dough. Results in this Table showed that, water absorption ranged from 51.2 to $58.1 \%$ having the lower

\begin{tabular}{|c|c|c|c|c|c|c|c|c|c|}
\hline \multirow{2}{*}{ Variety } & \multirow{2}{*}{$\begin{array}{c}\text { Water absorption } \\
(\%)\end{array}$} & \multicolumn{8}{|c|}{ Torque (Nm) } \\
\hline & & DDT & $\mathrm{C}_{1}$ & $\mathrm{C}_{2}$ & $\mathbf{C}_{3}$ & $\mathrm{C}_{4}$ & $\mathbf{C}_{5}$ & $\begin{array}{l}\text { Amplitude } \\
\text { (Nm) }\end{array}$ & $\begin{array}{l}\text { Stability time } \\
\text { (min) }\end{array}$ \\
\hline Gemmeiza 9 & 51.2 & 1.48 & 1.10 & 0.31 & 1.84 & 1.62 & 2.45 & 0.10 & 3.03 \\
\hline Seds 12 & 58.1 & 1.48 & 1.10 & 0.44 & 1.90 & 1.72 & 2.67 & 0.10 & 4.02 \\
\hline
\end{tabular}
value in Gemmeiza 9 and the higher value in Seds 12.

Table (3): Rheological characteristics of wheat flour dough for the two wheat varieties 
Water absorption is the quantity of water required for adequate consistency, in order to obtain a torque of $\mathrm{C}_{1}=1.1 \mathrm{Nm}$ according to the standard Chopin + protocol used. $\mathrm{C}_{1}$ was taken at the start of the test, during the constant temperature period in which dough mixing characteristics are measured, within the stipulated $1.10 \mathrm{Nm}$ for all the samples. The values recorded $1.10 \mathrm{Nm}$. This property is important because it affects the quality of the products (brioche bread) and shelf life.

Dough development time (DDT) is the time needed to reach $\mathrm{C}_{1}$; it's strongly influenced by flour protein \& particle and gluten properties size. Samples recorded $1.48 \mathrm{~min}$ for both. In this concern Elemo et al. (2017) reported that dough development time (DDT) was ranged from 0.63 to $2.17 \mathrm{~min}$.

Catteral (1995), Rasper and Walker (2000) stated that, Amplitude is the curve width at $\mathrm{C}_{1}$. It indicates the protein quality or elasticity of the dough, the higher the figure the more elastic is the dough. Values were the same for two samples recording 0.10 $\mathrm{Nm}$.

Dough stability is the time (in minutes) when the torque exceeds $C_{1}$ and it measures the resistance of dough to kneading. The higher the figure, the stronger is the dough. Seds 12 having the higher dough stability which was 4.02 min versus $3.03 \mathrm{~min}$ for Gemmeiza variety.

The low stability and development of the dough made from Gemmeiza 9 flour might be due to the low water absorption, which seemed to influence its stability. This might be due to the competition between the starch granules and flour proteins for available water, which consequently affected the visco-elastic behaviour of the dough. Hatcher et al. (2009), Catteral (1995) and Rasper and Walker (2000) also added that, gluten quality and resistance to the kneading forces are factors affecting dough stability.

Wheat variety, agro ecological conditions during planting, protease activity and milling conditions are factors play an important role in gluten properties.

Dough weakening is measured by $\mathrm{C}_{2}$, which express the function of mechanical work and temperature due to protein reduction. The increases dough temperature during mixing, the decreases its consistency. The degree of decrement depends on protein quality. Seds 12 recorded $0.44 \mathrm{Nm}$ (the higher value) versus $0.31 \mathrm{Nm}$ for Gemmeiza 9 (the lower value). The recorded results are agreed with those obtained by Elemo et al. (2017). They found that, $\mathrm{C}_{2}$ is ranged from 0.39 to $0.46 \mathrm{Nm}$.

Starch gelatinization during heating and cooking stage was expressed by $\mathrm{C}_{3}$. It describes the starch behavior which is observed as an increase in consistency of the dough and its increase is depending on the quality of the starch. Seds 12 is also scored higher value $(1.90 \mathrm{Nm})$ when compared with Gemmeiza 9 which scored $1.84 \mathrm{Nm}$.

Physical breakdown of the starch granules and amylase activity are associated with a reduction of viscosity in the fourth stage.
The torque at $\mathrm{C}_{4}$ gives an indication about the rate of enzymatic hydrolysis and the stability of the hot gel formed. The lower the value, the less stable is the starch gel. Seds 12 had $1.72 \mathrm{Nm}$ implying the most stable gel in the hot phase. Meanwhile, Gemmeiza 9 had $1.62 \mathrm{Nm}$. The torque $\left(\mathrm{C}_{5}\right)$ is an indication of retrogradation or ordering of starch molecules during the cooling phase and implies how shelf stable the flour product will be. It was $2.67 \mathrm{Nm}$ for Seds 12 and 2.45 $\mathrm{Nm}$ for Gemmeiza 9.

The Mixolab indices of the wheat dough for both varieties were represented in Table (4) and Figure (1).

Table (4): Mixolab indices of flour from the different wheat varieties

\begin{tabular}{|c|c|c|}
\hline \multirow{2}{*}{ Parameter } & \multicolumn{2}{|c|}{ Wheat variety } \\
\hline & Gemmeiza 9 & Seds 12 \\
\hline Absorption & 1 & 1 \\
\hline Mixing & 1 & 1 \\
\hline Gluten & 6 & 6 \\
\hline Viscosity & 5 & 5 \\
\hline Amylase & 7 & 7 \\
\hline Retrogradation & 5 & 5 \\
\hline
\end{tabular}

The absorption index express the function of flour components (starch, protein, fiber and additives) in this respect both varieties recorded (1).

Meanwhile, mixing index shows the behavior of the dough during mixing, accounting for dough stability, development and weakening. The higher value of Mixing indexes the higher dough stability in mixing. The two samples could be considered to have low mixing index as the recorded values was (1).

Gluten index represents the behavior of dough, gluten while raising temperature. High value revealed high gluten resistance to heating. The Gluten index for Gemmeiza 9 and Seds 12 was 6.

Viscosity index showed that, the both varieties of wheat had the same index (5). This index express the maximum viscosity during heating which depending on both amylase and starch quality.

Amylase activity index is a function of the starch ability to stand breakdown. A high value corresponds to low amylase activity and vice versa. The index for two varieties was 7 .

Retrogradation index is a function of association and re-arrangement of starch granules. The value (5) was the same at both samples. These results agree with Elemo et al. (2017). Of the local wheat tested samples, Gemmeiza 9 had the least values when it compared with Seds 12. So, the flour used in the dough was Seds 12. 


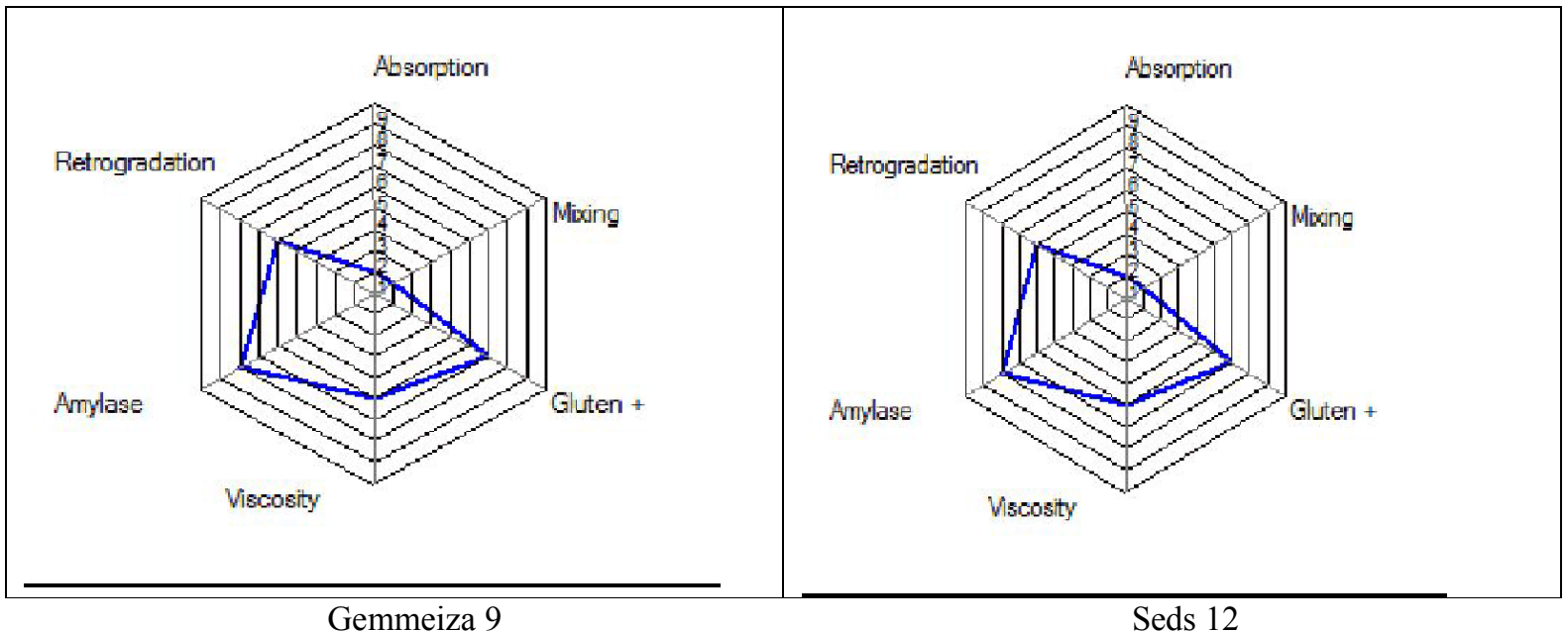

Figure (1): Mixolab profile for Gemmeiza 9 and Seds 12 variety

Chemical composition, minerals, total phenols and DPPH scavenging activity of GCS:

Chemical composition, minerals, total phenols and DPPH scavenging activity of GCS are shown in Table (5). From this Table it could be concluded that, GCS contain high amounts of ash which indicate that, it is a good source of minerals. Low moisture content is an indicator of stability, quality, and increased shelf life of seeds (And and Alli, 1988). GCS have high food energy resulting from high protein and lipid contents.

Table (5): Chemical composition, minerals, total phenols and DPPH scavenging activity of GCS

\begin{tabular}{|c|c|}
\hline Parameters analysis of GCS & Mean \pm SD \\
\hline \multicolumn{2}{|c|}{ Chemical analysis $(\%)$} \\
\hline Moisture & $5.31 \pm 0.11$ \\
\hline Protein & $20.68 \pm 2.76$ \\
\hline Fat & $26.79 \pm 0.71$ \\
\hline Ash & $4.25 \pm 0.55$ \\
\hline Crude fiber & $3.38 \pm 0.57$ \\
\hline Total Carbohydrate & $39.49 \pm 2.71$ \\
\hline \multicolumn{2}{|c|}{ Minerals ( mg/100g) } \\
\hline $\mathbf{F e}$ & $10.09 \pm 0.40$ \\
\hline Mn & $2.90 \pm 0.01$ \\
\hline $\mathbf{Z n}$ & $5.46 \pm 0.06$ \\
\hline $\mathbf{C u}$ & $7.15 \pm 0.83$ \\
\hline $\mathbf{C a}$ & $383.58 \pm 5.57$ \\
\hline Mg & $686.86 \pm 4.57$ \\
\hline $\mathbf{P}$ & $959.13 \pm 10.46$ \\
\hline $\mathbf{K}$ & $2397.82 \pm 26.15$ \\
\hline $\mathbf{N a}$ & $20.08 \pm 0.35$ \\
\hline $\begin{array}{l}\text { Total phenols (mg/100g) as } \\
\text { Gallic acid }\end{array}$ & $44.49 \pm 0.05$ \\
\hline DPPH scavenging activity (\%) & $47.10 \pm 1.02$ \\
\hline
\end{tabular}

Proximate composition (\%) of L. sativum seeds reported by Zia-Ul-Haq et al. (2012) indicated the presence of appreciable amounts of protein $(24.2 \mathrm{~g})$, lipids $(23.2 \mathrm{~g})$, carbohydrates $(30.7 \mathrm{~g})$, fiber $(11.9 \mathrm{~g})$, ash $(7.1 \mathrm{~g})$, and moisture $(2.9 \mathrm{~g})$.

Mineral contents of seeds varied between species. A study by Sofowora (1982) and Gokavi et al. (2004) stated that, potassium constituted the major mineral in GCS $1236.51 \mathrm{mg} / 100 \mathrm{~g}$, while zinc and manganese contents are low $(6.99$ and $2.00 \mathrm{mg} / 100 \mathrm{~g}$, respectively). It is also a good source of calcium, phosphorus, and magnesium (266.35, 608.63 and $339.23 \mathrm{mg} / 100 \mathrm{~g}$ ). With these minerals content, it can be used for increasing the number of supplementary food products.

The differ in some mineral contents was refer to like varies depending upon plant variety, agronomical practices, phase of collection, climatic and geological conditions for the area from where seeds are collected (Zia-Ul-Haq et al., 2012).

Therefore, GCS powder contains considerable amounts of protein, fat, fibers and minerals which are inserted into many functional foods.

\section{Phytochemicals:}

The antioxidant properties depend on the phenolic compounds of GCS were presented in Table (5). The mean value from total phenols of GCS was $44.49 \mathrm{mg} / 100 \mathrm{~g}$ as Gallic acid revealing appreciable amounts and considered a good source for phenolic compounds.

In this respect, there were different estimated values refereeing to difference in extraction solvent. Aydemir and Becerik (2011) reported that, the mean of total phenols content in GCS was $61.4 \mathrm{mg} / 100 \mathrm{~g}$ while, in a study by Yadav et al. (2011) they found that, the mean value of total phenols was $4.46 \mathrm{mg} \mathrm{GAE} / \mathrm{g}$ in ethanolic extract.

\section{Free radical scavenging activity by DPPH Method:}

In the same Table (5), Garden cress seeds showed better inhibition of DPPH which was 47.10 $\mathrm{mg} / 100 \mathrm{~g}$ of methanolic extracts and comparing with 
standard free radical scavenger BHA at concentration 10,50 and $100 \mu \mathrm{g}$.

Due to high content from phenolic compounds and good free radical scavenging potential of GCS, it could be using it in fortification to prepare balanced diet that helping in combination and exploiting its rich nutritional value to the developed food.
Sensory properties of brioche bread samples with GCS powder:

Sensory evaluation is an important factor, since it reveals the consumers acceptance for the product. Table (6) and Figure (2) illustrated the sensory evaluation for control and brioche bread samples with different concentrations of GCS.

Table (6): Sensory evaluation of brioche bread made with GCS powder

\begin{tabular}{lccccc}
\hline Treatments & Color & Aroma & Texture & Flavor & $\begin{array}{c}\text { Overall } \\
\text { acceptability }\end{array}$ \\
\hline Control & $4.14 \pm 0.76^{\mathrm{a}}$ & $3.97 \pm 0.91^{\mathrm{a}}$ & $3.88 \pm 0.82^{\mathrm{a}}$ & $3.76 \pm 0.85^{\mathrm{a}}$ & $3.97 \pm 0.99^{\mathrm{a}}$ \\
T1 & $3.80 \pm 0.84^{\mathrm{ab}}$ & $3.64 \pm 1.03^{\mathrm{ab}}$ & $3.55 \pm 0.94^{\mathrm{a}}$ & $3.29 \pm 0.91^{\mathrm{bc}}$ & $3.64 \pm 1.03^{\mathrm{ab}}$ \\
T2 & $3.80 \pm 0.84^{\mathrm{ab}}$ & $3.77 \pm 0.85^{\mathrm{ab}}$ & $3.61 \pm 0.86^{\mathrm{a}}$ & $3.54 \pm 0.65^{\mathrm{abc}}$ & $3.93 \pm 0.72^{\mathrm{a}}$ \\
T3 & $3.87 \pm 0.81^{\mathrm{ab}}$ & $3.54 \pm 1.03^{\mathrm{ab}}$ & $3.46 \pm 0.87^{\mathrm{ab}}$ & $3.58 \pm 0.86^{\mathrm{ab}}$ & $3.61 \pm 1.01^{\mathrm{ab}}$ \\
T4 & $3.63 \pm 1.04^{\mathrm{bc}}$ & $3.32 \pm 1.05^{\mathrm{bc}}$ & $3.10 \pm 0.91^{\mathrm{c}}$ & $3.15 \pm 0.86^{\mathrm{c}}$ & $3.25 \pm 0.96^{\mathrm{bc}}$ \\
T5 & $3.28 \pm 1.23^{\mathrm{c}}$ & $2.98 \pm 1.13^{\mathrm{c}}$ & $2.77 \pm 0.94^{\mathrm{d}}$ & $2.69 \pm 1.04^{\mathrm{d}}$ & $2.83 \pm 1.18^{\mathrm{c}}$ \\
\hline Va & & & &
\end{tabular}

Values are mean $\pm \mathrm{SD}$; Values are taken in triplicate

Alphabets with different superscripts shows significant difference at $5 \%$ level of significance

T0:100\% wheat flour and zero $\%$ GCS. T1:99\% wheat flour and 1\% GCS. T2:98\% wheat flour and 2\% GCS. T3:97\% wheat flour and 3\% GCS. T4:96\% wheat flour and 4\% GCS. T5:95\% wheat flour and 5\% GCS.

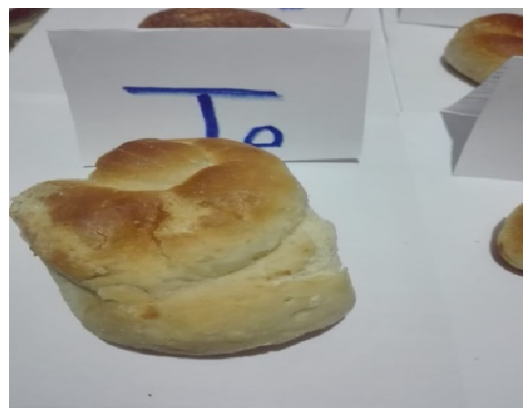

a

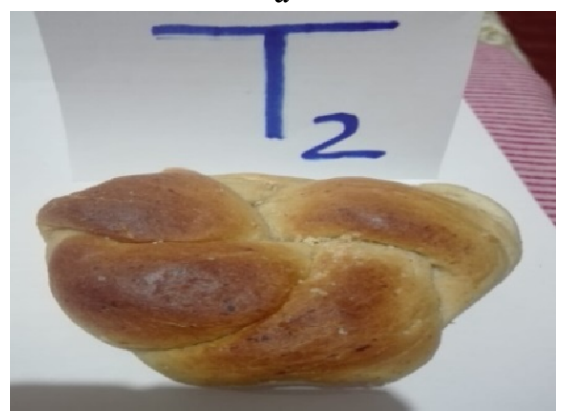

c

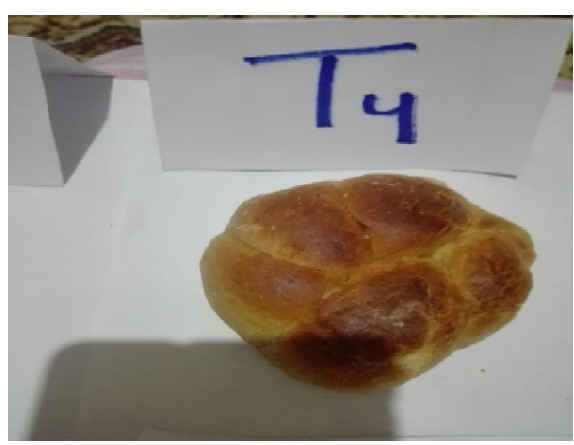

$\mathbf{e}$

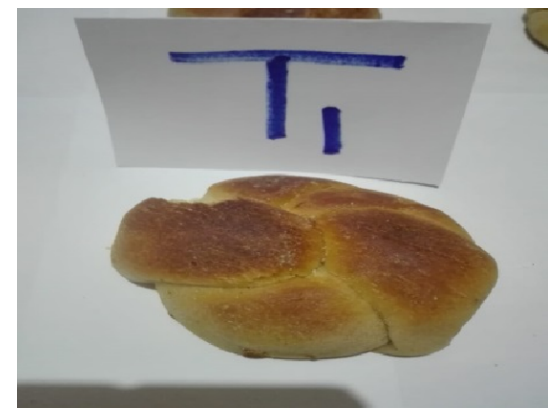

$\mathbf{b}$

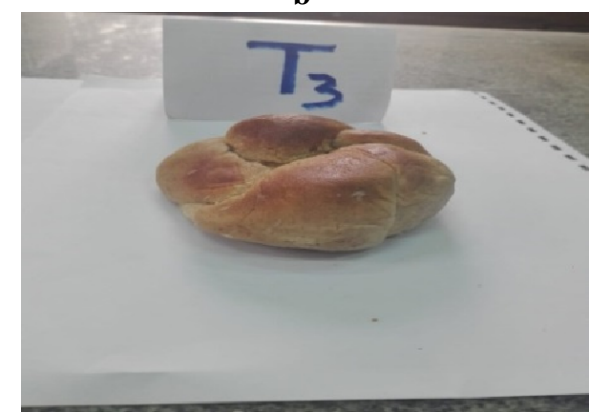

d

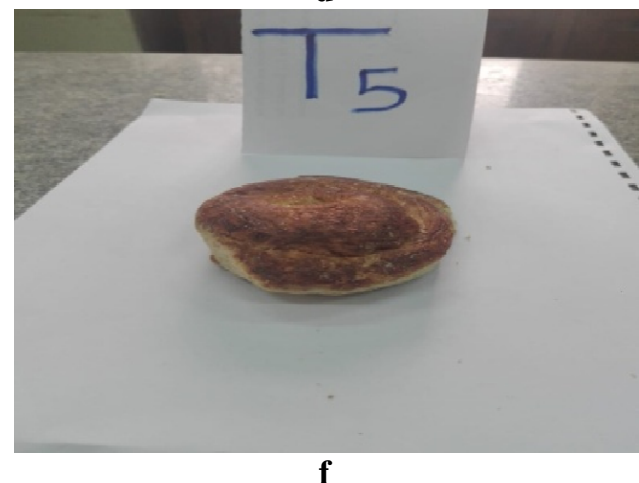

f

Figure (2): Brioche bread made by using different concentrations from GCS a: $100 \%$ wheat flour, b: $1 \% \mathrm{GCS}, \mathrm{c}: 2 \% \mathrm{GCS}, \mathrm{d}: 3 \% \mathrm{GCS}$ e: $4 \% \mathrm{GCS}$ and f: $5 \% \mathrm{GCS}$ 
From Table (6) it could be noticed that, control brioche sample recorded the highest scores for all attributes. Brioche bread containing 1,2 and 3\% of GCS powder had high score for overall acceptability, $3.64,3.93$ and 3.61 , respectively compared with other brioche samples and there were no significant difference with the control brioche. It could be believed that GCS-added brioche up to $3 \%$ had color, aroma, texture and flavor scores, nearly the same to that of the control brioche. In the case of 4 and $5 \%$ GCS-added brioche, panelist assigned a lower score than the control brioche for all parameters.

Statistical analysis of sensory scores indicated that the best overall acceptability of resulting brioche bread can be obtained by replacing wheat flour with 1$3 \%$ GCS powder in brioche formulation.

\section{Chemical analysis of brioche samples}

The chemical composition of brioche bread samples containing different levels of GCS powder were summarized in Table (7). Basically, moisture, protein, fat and ash contents increased directly proportional to the level of GCS powder added in the formulation of brioche. Statistical analysis revealed that, control brioche bread was significantly $(\mathrm{p}<0.05)$ scored the lowest moisture, protein, fat and ash contents $(34.02,12.6915 .31$ and $1.08 \%$, respectively) when compared with all samples.

Regarding sample contents from fiber, T3, T4 and $\mathrm{T} 5$ had the highest content from fiber $(1.73,1.73$ and $1.85 \%$ ) when they compared with $\mathrm{T} 1$ and $\mathrm{T} 2$ samples (1.47 and $1.52 \%)$. However, these differences did not show any significance $(\mathrm{P}>0.05)$ neither the previous three samples nor control brioche bread. Meanwhile, T3, T4 and T5 showed significant differences $(\mathrm{P}<0.05)$ between its contents and control bread sample $(0.80 \%)$.

On the other hand, samples contents from carbohydrates $(\mathrm{CHO})$ decreased directly proportional to the level of GCS powder added in the formulation of brioche, as there was a significant difference $(p<0.05)$ between control sample content from carbohydrates and all other samples. This may be due to the high content of this samples from protein which affecting (decrease) its content (percentage) from $\mathrm{CHO}$.

Table (7): Chemical composition of brioche bread samples containing GCS powder

\begin{tabular}{|c|c|c|c|c|c|c|c|}
\hline Treatments & $\begin{array}{c}\text { Moisture } \\
(\%)\end{array}$ & $\begin{array}{c}\text { Protein } \\
(\%)\end{array}$ & $\begin{array}{l}\text { Fat } \\
(\%)\end{array}$ & $\begin{array}{l}\text { Ash } \\
\text { (\%) }\end{array}$ & $\begin{array}{l}\text { Fiber } \\
(\%)\end{array}$ & $\begin{array}{c}\text { Total CHO } \\
(\%)\end{array}$ & $\begin{array}{c}\text { Total Calories } \\
\text { (K.cal.) }\end{array}$ \\
\hline Control & $34.02 \pm 0.01^{\mathrm{f}}$ & $12.69 \pm 0.05^{\mathrm{f}}$ & $15.31 \pm 0.44^{\mathrm{c}}$ & $1.08 \pm 0.01^{\mathrm{e}}$ & $0.80 \pm 0.54^{b}$ & $36.33 \pm 0.64^{\mathrm{a}}$ & $331.77 \pm 1.29^{\mathrm{a}}$ \\
\hline $\mathbf{T 1}$ & $34.70 \pm 0.10^{\mathrm{e}}$ & $12.85 \pm 0.01^{\mathrm{e}}$ & $16.77 \pm 0.67^{\mathrm{ab}}$ & $1.40 \pm 0.01^{\mathrm{d}}$ & $1.47 \pm 0.42^{\mathrm{ab}}$ & $32.82 \pm 1.01^{\mathrm{b}}$ & $333.49 \pm 2.17^{\mathrm{a}}$ \\
\hline $\mathbf{T} 2$ & $34.84 \pm 0.02^{\mathrm{d}}$ & $13.09 \pm 0.05^{\mathrm{d}}$ & $16.79 \pm 0.64^{\mathrm{ab}}$ & $1.42 \pm 0.01^{\mathrm{c}}$ & $1.52 \pm 0.37^{\mathrm{ab}}$ & $32.34 \pm 0.41^{b}$ & $332.83 \pm 4.65^{\mathrm{a}}$ \\
\hline T3 & $35.21 \pm 0.10^{c}$ & $13.26 \pm 0.02^{\mathrm{c}}$ & $17.01 \pm 0.45^{\mathrm{a}}$ & $1.44 \pm 0.01^{\mathrm{b}}$ & $1.73 \pm 0.52^{\mathrm{a}}$ & $31.34 \pm 1.01^{\mathrm{c}}$ & $331.58 \pm 1.30^{\mathrm{a}}$ \\
\hline T4 & $35.60 \pm 0.10^{\mathrm{b}}$ & $13.45 \pm 0.01^{\mathrm{b}}$ & $17.13 \pm 0.18^{\mathrm{a}}$ & $1.45 \pm 0.00^{\mathrm{a}}$ & $1.73 \pm 0.59^{\mathrm{a}}$ & $30.62 \pm 0.39^{c}$ & $330.52 \pm 2.46^{\mathrm{ab}}$ \\
\hline $\mathbf{T 5}$ & $35.85 \pm 0.05^{\mathrm{a}}$ & $13.66 \pm 0.02^{\mathrm{a}}$ & $17.14 \pm 0.00^{\mathrm{a}}$ & $1.46 \pm 0.01^{\mathrm{a}}$ & $1.85 \pm 0.05^{\mathrm{a}}$ & $30.11 \pm 0.15^{\mathrm{c}}$ & $328.68 \pm 0.68^{\mathrm{ab}}$ \\
\hline
\end{tabular}

Values are mean $\pm \mathrm{SD}$; Values are taken in triplicate

Alphabets with different superscripts shows significant difference at 5\% level of significance; T0:100\% wheat flour and zero\% GCS. T1:99\% wheat flour and 1\% GCS. T2:98\% wheat flour and 2\% GCS. T3:97\% wheat flour and 3\% GCS. T4:96\% wheat flour and $4 \%$ GCS. T5:95\% wheat flour and 5\% GCS.

With regard to total calories, insignificant differences $(p>0.05)$ were observed neither between control and all samples nor among samples.

In this respect, Singh and Paswan (2017) stated that, the powder of garden cress seeds was used in fortification of different items of food. Hence, it can potentially be used as a functional food. In our study it is used in fortification of brioche dough.

A study by Kasabe et al. (2012) to uncover the chemical composition of garden cress (total carbohydrates and proteins) the results revealed that the seeds of Garden cress possess nutritional value.
The same attitude was observed with Elizabeth and Poojara (2014). They stated that, garden cress seeds are an important food stuff loaded with nutrients as well as health enhancing properties. Shail et al. (2016) also, found that the seeds of GC contained 2.88, $24.19,23.19,30.74,11.9$ and $7.1 \%$ from moisture, protein, fat, carbohydrates, fiber and ash, respectively. These results are matching with our study and explain the significant differences between control and the used concentrations from GCS which rich in the previous nutrients, especially T4 and T5 samples which recorded significant differences when comparing with control sample. 


\section{Minerals analysis of brioche samples:}

Table (8) illustrated the macro- and microminerals concentration of brioche bread samples. Replacement of wheat flour with GCS powder increased the macro-mineral levels, particularly the potassium, phosphorus and calcium concentration of brioche samples compared to the control. Brioche in which wheat flour replaced with 5\% GCS had higher level $(\mathrm{p}<0.05)$ of macro-minerals and micro-minerals such as zinc, iron and cupper than the control and other replaced samples.

Conversion of wheat into wheat flour by milling reduces the original level of nutrients in the wheat. Therefore, the minerals content of bread varies considerably within and between different bread types depending on the flour processing as on the macro-and micro-mineral concentration.

In this respect, Elizabeth and Poojara (2014) in a study to modifying snacks with GCS they found that, Garden cress seeds are significant source of iron, also minerals like calcium and phosphorus. Nathiya and Vigasini (2014) found that, the combination of GCS in foods have shown remarkable increase in iron and protein content. Garden cress seed rich source of protein, iron and minerals (Patil et al., 2015). The same attitude was observed in a study by Kasabe et al. (2012) and Shail et al. (2016).

Table (8): Minerals content $(\mathrm{mg} / 100 \mathrm{~g})$ of brioche bread samples containing GCS powder

\begin{tabular}{|c|c|c|c|c|c|c|c|c|c|c|c|}
\hline Treatments & $\mathrm{Fe}$ & Mn & $\mathbf{Z n}$ & $\mathrm{Cu}$ & $\mathbf{C a}$ & Mg & $\mathbf{P}$ & $\mathbf{K}$ & $\mathbf{N a}$ & $\mathrm{Ca} / \mathrm{P}$ & $\mathrm{Na} / \mathrm{K}$ \\
\hline Control & $\begin{array}{l}1.28 \pm \\
0.08^{\mathrm{e}}\end{array}$ & $\begin{array}{c}0.33 \pm \\
0.01^{\mathrm{e}}\end{array}$ & $\begin{array}{l}1.23 \pm \\
0.01^{\mathrm{e}}\end{array}$ & $\begin{array}{l}2.19 \pm \\
0.17^{\mathrm{d}}\end{array}$ & $\begin{array}{c}373.11 \pm \\
0.78^{\mathrm{f}}\end{array}$ & $\begin{array}{c}363.43 \pm \\
1.75^{\mathrm{f}}\end{array}$ & $\begin{array}{c}184.88 \pm \\
0.40^{\mathrm{f}}\end{array}$ & $\begin{array}{c}461.85 \pm \\
0.61^{\mathrm{f}}\end{array}$ & $\begin{array}{c}21.14 \pm \\
0.24^{\mathrm{d}}\end{array}$ & 2.02 & 0.05 \\
\hline T1 & $\begin{array}{l}1.35 \pm \\
0.09^{\mathrm{de}}\end{array}$ & $\begin{array}{l}0.37 \pm \\
0.01^{d}\end{array}$ & $\begin{array}{l}1.33^{ \pm} \\
0.02^{\mathrm{d}}\end{array}$ & $\begin{array}{l}2.49 \pm \\
0.04^{\mathrm{c}}\end{array}$ & $\begin{array}{c}379.07 \pm \\
1.25^{\mathrm{e}}\end{array}$ & $\begin{array}{c}370.20 \pm \\
1.06^{\mathrm{e}}\end{array}$ & $\begin{array}{c}197.38 \pm \\
1.86^{\mathrm{e}}\end{array}$ & $\begin{array}{c}493.98 \pm \\
3.95^{\mathrm{e}}\end{array}$ & $\begin{array}{c}21.97 \pm \\
0.31^{\mathrm{c}}\end{array}$ & 1.92 & 0.04 \\
\hline $\mathbf{T 2}$ & $\begin{array}{l}1.44 \pm \\
0.10^{\mathrm{d}}\end{array}$ & $\begin{array}{l}0.43 \pm \\
0.01^{\mathrm{c}}\end{array}$ & $\begin{array}{l}1.41 \pm \\
0.01^{\mathrm{c}}\end{array}$ & $\begin{array}{c}2.55 \pm \\
0.08^{\mathrm{c}}\end{array}$ & $\begin{array}{c}381.92 \pm \\
0.85^{\mathrm{d}}\end{array}$ & $\begin{array}{c}373.20^{ \pm} \\
0.82^{\mathrm{d}}\end{array}$ & $\begin{array}{c}204.83 \pm \\
0.88^{\mathrm{d}}\end{array}$ & $\begin{array}{c}512.28 \pm \\
1.84^{\mathrm{d}}\end{array}$ & $\begin{array}{c}22.45 \pm \\
0.22^{\mathrm{b}}\end{array}$ & 1.86 & 0.04 \\
\hline T3 & $\begin{array}{l}1.64 \pm \\
0.08^{\mathrm{c}}\end{array}$ & $\begin{array}{l}0.45^{ \pm} \\
0.01^{\mathrm{c}}\end{array}$ & $\begin{array}{l}1.44 \pm \\
0.01^{\mathrm{c}}\end{array}$ & $\begin{array}{l}2.68 \pm \\
0.04^{\mathrm{c}}\end{array}$ & $\begin{array}{c}386.45 \pm \\
0.83^{\mathrm{c}}\end{array}$ & $\begin{array}{c}377.32 \pm \\
2.24^{\mathrm{c}}\end{array}$ & $\begin{array}{c}210.05 \pm \\
1.41^{\mathrm{c}}\end{array}$ & $\begin{array}{c}524.15 \pm \\
3.55^{\mathrm{c}}\end{array}$ & $\begin{array}{c}22.60 \pm \\
0.19^{\mathrm{b}}\end{array}$ & 1.84 & 0.04 \\
\hline T4 & $\begin{array}{l}1.80^{ \pm} \\
0.08^{\mathrm{b}}\end{array}$ & $\begin{array}{l}0.52 \pm \\
0.01^{b}\end{array}$ & $\begin{array}{l}1.49 \pm \\
0.03^{b}\end{array}$ & $\begin{array}{l}3.18 \pm \\
0.07^{\mathrm{b}}\end{array}$ & $\begin{array}{c}391.94 \pm \\
0.92^{\mathrm{a}}\end{array}$ & $\begin{array}{c}382.99 \pm \\
1.01^{\mathrm{b}}\end{array}$ & $\begin{array}{c}223.35 \pm \\
1.36^{\mathrm{b}}\end{array}$ & $\begin{array}{c}559.56 \pm \\
2.51^{\mathrm{b}}\end{array}$ & $\begin{array}{c}22.81 \pm \\
0.09^{\mathrm{a}}\end{array}$ & 1.75 & 0.04 \\
\hline T5 & $\begin{array}{r}2.05 \pm \\
0.02^{\mathrm{a}}\end{array}$ & $\begin{array}{c}0.59 \pm \\
0.04^{\mathrm{a}}\end{array}$ & $\begin{array}{l}1.72 \pm \\
0.09^{\mathrm{a}}\end{array}$ & $\begin{array}{l}5.57 \pm \\
0.39^{\mathrm{a}}\end{array}$ & $\begin{array}{c}388.68 \pm \\
2.29^{\mathrm{b}}\end{array}$ & $\begin{array}{c}386.82 \pm \\
2.14^{\mathrm{a}}\end{array}$ & $\begin{array}{c}238.93 \pm \\
3.27^{\mathrm{a}}\end{array}$ & $\begin{array}{c}596.98 \pm \\
8.33^{\mathrm{a}}\end{array}$ & $\begin{array}{c}22.91 \pm \\
0.00^{\mathrm{a}}\end{array}$ & 1.63 & 0.04 \\
\hline
\end{tabular}

Values are mean $\pm \mathrm{SD}$; Values are taken in triplicate

Alphabets with different superscripts shows significant difference at 5\% level of significance; T0:100\% wheat flour and zero $\%$ GCS. T1:99\% wheat flour and 1\% GCS. T2:98\% wheat flour and 2\% GCS. T3:97\% wheat flour and 3\% GCS. T4:96\% wheat flour and $4 \%$ GCS. T5:95\% wheat flour and 5\% GCS.

The brioche samples prepared by replacing wheat flour with $\mathrm{GCS}$ had $\mathrm{Na} / \mathrm{K}$ ratio 0.04 and $\mathrm{Ca} / \mathrm{P}$ ratio ranged from 1.63 to 1.92 which considered close to recommended ratio (Table 8). Thus, the brioche bread is considered an advantage for people who suffering from renal and blood pressure problems in addition for children, women and men with bone problems.

To recognize the impact of significant difference from fiber between control, T1 and T2 samples from a side and samples No 3, 4 and 5 from another side, and to study the effect of adding GCS powder to wheat flour on its rheological characteristics, Mixolab indices for sample No. 4 was done as an example. Tables (9 and 10) and Figure (3) revealed that, there was enhancing in dough properties for T4 sample comparing with properties of two varieties of wheat flour represented in Table (4) representing especially in increase the percentage of water absorption to $69.5 \%$ when adding GCS powder to wheat flour. Also, rest of parameters.

Table (9): Rheological characteristics of (wheat flour Seds 12 \& 4\% GCS) sample No 4

\begin{tabular}{|c|c|c|c|c|c|c|c|c|c|}
\hline \multirow{2}{*}{ Wheat sample } & \multirow{2}{*}{$\begin{array}{c}\text { Water } \\
\text { absorption \% }\end{array}$} & \multicolumn{8}{|c|}{ Torque (Nm) } \\
\hline & & DDT & $\mathbf{C}_{1}$ & $\mathbf{C}_{2}$ & $\mathbf{C}_{3}$ & $\mathrm{C}_{4}$ & $\mathrm{C}_{5}$ & $\begin{array}{c}\text { Amplitude } \\
\text { (Nm) }\end{array}$ & $\begin{array}{c}\text { Stability } \\
\text { (min) }\end{array}$ \\
\hline NO 4 & 69.5 & 1.35 & 1.10 & 0.51 & 1.70 & 1.84 & 2.88 & 0.09 & 9.55 \\
\hline
\end{tabular}


Table (10): Mixolab indices of sample No 4 dough

Parameter Sample No 4

\begin{tabular}{lc}
\hline Absorption & 4 \\
Mixing & 4 \\
Gluten & 5 \\
Viscosity & 4 \\
Amylase & 8 \\
Retrogradation & 7 \\
\hline
\end{tabular}

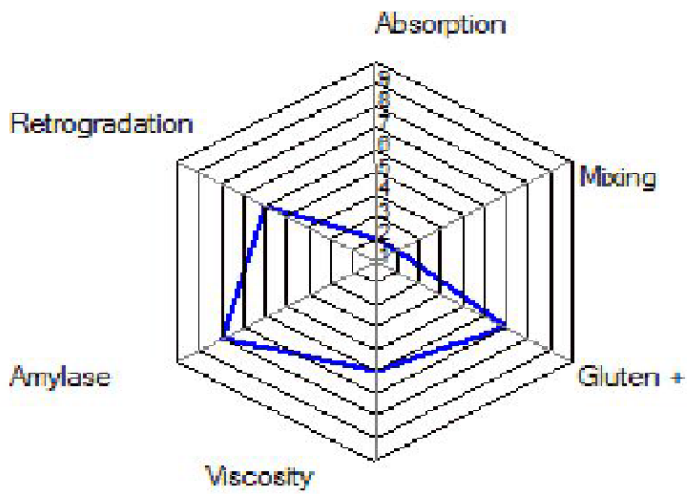

Fig (3): Mixolab indices of sample No 4

These results were a line with the previous studies concerning the benefits and nutritional values of adding GCS powder. So it could be use Egyptian wheat flour (72\% extraction) in making brioche bread,
Fino bread...etc and can be used easily in pilot plants of the Egyptian bakery to arrive strategic Egyptian government goal.

\section{Physical properties of brioche bread samples containing GCS powder:}

Water activities of prepared brioche samples are illustrated in Table (11). There was a significantly differences in water activity in all samples it ranged from 0.83 to 0.87 compared with control sample was 0.86. Altamirano-Fortoul and Rosell (2011) found that water activity of brioche and small brioche was 0.66 during the first $4 \mathrm{~h}$ after baking and values after $24 \mathrm{~h}$ storage was 0.59 .

Concerning the data of brioche crumb color, the lightness $\left(\mathrm{L}^{*}\right)$ value of brioche decreased significantly $(\mathrm{p}<0.05)$ from 79.65 to 55.61 compared with control 83.82 by increasing levels of adding of GCS powder from $1 \%$ to $5 \%$.

The yellowness $\left(b^{*}\right)$ value of brioche showed insignificantly difference between control and all treatments except T5 $(\mathrm{P}<0.05)$. The values were ranged from 21.28 to 22.40 .

\section{Baking freshness property of brioche bread samples}

Table (12) explained the changes occurred during the storage period. Bread staling is a complex process that occurs during bread storage. It is delayed the deterioration progress of qualities such as taste, firmness, etc. The mechanism of bread staling is still not clear yet even though it has been studied for 150 years (Xie et al., 2004). Alkaline water retention capacity (AWRC) of the brioche could be considered as an indicator for staling and freshness. Therefore, it was estimated for each selected GCS powder addition at zero time and after storage periods (24, 48 and $72 \mathrm{~h}$ ) as shown Table (12). The presented data showed that, decreased of AWRC by increasing addition percent of GCS powder, in all tested brioche sample. T5 had the lowest value of AWRC, being, 225.44, 221.80, 218.12 and 206.48 at $0,24,48$ and $72 \mathrm{~h}$, respectively.

Table (11): Water activity and color attributes of brioche bread containing GCS powder

\begin{tabular}{|c|c|c|c|c|}
\hline \multirow{2}{*}{ Treatments } & \multirow{2}{*}{$\mathbf{a}_{\mathbf{w}}$} & \multicolumn{3}{|c|}{ Color } \\
\hline & & $\mathbf{L}^{*}$ & $a^{*}$ & $\mathbf{b}^{*}$ \\
\hline Control & $0.86 \pm 0.001^{\mathrm{c}}$ & $83.82 \pm 0.90^{\mathrm{a}}$ & $-2.83 \pm 0.13^{f}$ & $22.40 \pm 0.97^{\mathrm{a}}$ \\
\hline T1 & $0.83 \pm 0.004^{\mathrm{e}}$ & $79.65 \pm 1.63^{b}$ & $-1.72 \pm 0.12^{\mathrm{e}}$ & $21.91 \pm 0.99^{\mathrm{ab}}$ \\
\hline $\mathbf{T} 2$ & $0.88 \pm 0.001^{\mathrm{a}}$ & $79.33 \pm 1.03^{b}$ & $-0.58 \pm 0.09^{\mathrm{d}}$ & $21.84 \pm 0.75^{\mathrm{ab}}$ \\
\hline $\mathbf{T 3}$ & $0.85 \pm 0.003^{\mathrm{d}}$ & $70.28 \pm 3.05^{\mathrm{c}}$ & $0.63 \pm 0.36^{\mathrm{c}}$ & $21.59 \pm 0.25^{\mathrm{ab}}$ \\
\hline $\mathbf{T 4}$ & $0.85 \pm 0.013^{\mathrm{d}}$ & $63.87 \pm 1.59^{\mathrm{d}}$ & $1.42 \pm 0.31^{\mathrm{b}}$ & $21.57 \pm 0.24^{\mathrm{ab}}$ \\
\hline T5 & $0.87 \pm 0.002^{\mathrm{b}}$ & $55.61 \pm 2.31^{\mathrm{e}}$ & $3.11 \pm 0.48^{\mathrm{a}}$ & $21.28 \pm 0.50^{\mathrm{b}}$ \\
\hline
\end{tabular}

Values are mean $\pm \mathrm{SD}$; Values are taken in triplicate

Alphabets with different superscripts shows significant difference at 5\% level of significance; T0: $100 \%$ wheat flour and zero $\%$ GCS. T1: $99 \%$ wheat flour and 1\% GCS. T2: $98 \%$ wheat flour and 2\% GCS. T3: $97 \%$ wheat flour and 3\% GCS. T4: $96 \%$ wheat flour and 4\% GCS. T5: $95 \%$ wheat flour and 5\% GCS. 
Table (12): Baking freshness properties of brioche bread samples

\begin{tabular}{lcccc}
\hline Samples & Zero time & $\mathbf{2 4 ~ h}$ & $\mathbf{4 8 ~ h}$ & $\mathbf{7 2 h}$ \\
\hline T0 & $251.31 \pm 1.91^{\mathrm{a}}$ & $248.07 \pm 2.59^{\mathrm{ab}}$ & $246.15 \pm 1.75 \mathrm{~b}^{\mathrm{c}}$ & $243.53 \pm 0.15^{\mathrm{cde}}$ \\
T1 & $248.49 \pm 6.26^{\mathrm{ab}}$ & $244.25 \pm 4.02^{\mathrm{cd}}$ & $237.09 \pm 1.13^{\mathrm{fg}}$ & $231.34 \pm 0.74^{\mathrm{ij}}$ \\
T2 & $242.33 \pm 0.43^{\mathrm{de}}$ & $240.52 \pm 0.42^{\mathrm{ef}}$ & $235.35 \pm 0.21^{\mathrm{gh}}$ & $221.80 \pm 0.59^{1}$ \\
T3 & $234.21 \pm 1.82^{\mathrm{ghi}}$ & $232.76 \pm 2.74^{\mathrm{hi}}$ & $231.34 \pm 0.74^{\mathrm{ij}}$ & $218.12 \pm 0.71^{\mathrm{m}}$ \\
T4 & $231.98 \pm 1.12^{\mathrm{hi}}$ & $227.73 \pm 1.79^{\mathrm{jk}}$ & $227.73 \pm 1.79^{\mathrm{jk}}$ & $213.15 \pm 3.51^{\mathrm{n}}$ \\
T5 & $225.44 \pm 0.45^{\mathrm{kl}}$ & $221.80 \pm 0.59^{1}$ & $218.12 \pm 0.71^{\mathrm{m}}$ & $206.48 \pm 0.13^{\mathrm{o}}$ \\
\hline
\end{tabular}

Values are mean $\pm \mathrm{SD}$; Values are taken in triplicate

Alphabets with different superscripts shows significant difference at 5\% level of significance; T0:100\% wheat flour and zero\% GCS. T1:99\% wheat flour and 1\% GCS. T2:98\% wheat flour and 2\% GCS. T3:97\% wheat flour and 3\% GCS. T4:96\% wheat flour and 4\% GCS. T5:95\% wheat flour and 5\% GCS.

This could be attributed to the high dietary fiber content of the garden cress seeds powder $30 \%$ in a study by (Doke and Guha, 2014). Fibers improve the nutritional value of bread but usually alter the rheological properties of dough, the quality and sensory properties of the final bread product. Bread containing fiber to a greater extent show especially longer shelf life than control samples (Gomez et al., 2003).

\section{Microbiological aspects of brioche bread samples:}

Concerning microbiological analysis Table (13) illustrates that, the number of total bacterial count increased by increasing storage period in low level of garden cress seed $(1: 3 \%)$ but in case of the high levels of cress seed (4 and 5\%) the counts decreased sharply and reached to 12 to 27 colonies per gram after 14 days of storage period. Statistical analysis showed significant differences $(\mathrm{p}<0.05)$ between T4 and T5 from one side and other treatments from the other side.

Table (13): Microbiological analysis for Brioche bread samples containing GCS powder

\begin{tabular}{|c|c|c|c|}
\hline Treatments & Time & Total Count $\times 10^{3}$ & Yeast $\&$ molds $\times 10^{3}$ \\
\hline Control & \multirow{6}{*}{ Zero time } & $24.00 \pm 0.10^{\mathrm{ef}}$ & $10.00 \pm 0.20^{\mathrm{de}}$ \\
\hline T1 & & $30.00 \pm 0.87^{\mathrm{de}}$ & $8.00 \pm 0.20^{\mathrm{def}}$ \\
\hline $\mathbf{T} 2$ & & $18.00 \pm 0.20^{\mathrm{fg}}$ & $4.30 \pm 0.18 \mathrm{f}^{\mathrm{g}}$ \\
\hline T3 & & $26.00 \pm 0.72^{\mathrm{ef}}$ & $1.50 \pm 0.04^{\mathrm{g}}$ \\
\hline T4 & & $4.60 \pm 0.60^{\mathrm{hi}}$ & $1.10 \pm 0.36^{\mathrm{g}}$ \\
\hline T5 & & $0.81 \pm 0.17^{\mathrm{hi}}$ & $0.56 \pm 0.03^{\mathrm{g}}$ \\
\hline Control & \multirow{6}{*}{ After 7 days } & $46.00 \pm 0.36^{\mathrm{bc}}$ & $21.33 \pm 0.33^{\mathrm{c}}$ \\
\hline T1 & & $48.00 \pm 0.69^{\mathrm{bc}}$ & $21.00 \pm 0.53^{\mathrm{c}}$ \\
\hline $\mathbf{T 2}$ & & $11.00 \pm 0.26^{\mathrm{gh}}$ & $2.00 \pm 0.04^{\mathrm{g}}$ \\
\hline T3 & & $31.33 \pm 0.61^{\text {de }}$ & $7.00 \pm 0.20^{\mathrm{ef}}$ \\
\hline T4 & & $2.40 \pm 0.36^{\mathrm{hi}}$ & $0.78 \pm 0.25^{\mathrm{g}}$ \\
\hline T5 & & $0.33 \pm 0.03^{\mathrm{i}}$ & $0.24 \pm 0.40^{\mathrm{g}}$ \\
\hline Control & \multirow{6}{*}{ After 14 days } & $71.00 \pm 1.87 \mathrm{a}$ & $45.00 \pm 0.62^{\mathrm{a}}$ \\
\hline T1 & & $52.00 \pm 1.11^{\mathrm{b}}$ & $39.00 \pm 0.44^{\mathrm{b}}$ \\
\hline $\mathbf{T} 2$ & & $2.40 \pm 0.07^{\mathrm{hi}}$ & $19.00 \pm 0.26^{\mathrm{c}}$ \\
\hline T3 & & $38.00 \pm 0.50^{\mathrm{cd}}$ & $11.33 \pm 0.23^{\mathrm{d}}$ \\
\hline T4 & & $0.01 \pm 0.17^{\mathrm{i}}$ & $0.02 \pm 0.44^{\mathrm{g}}$ \\
\hline T5 & & $0.03 \pm 0.35^{\mathrm{i}}$ & $0.02 \pm 0.36^{\mathrm{g}}$ \\
\hline
\end{tabular}

Staphylococcus aureus: ND

Values are mean $\pm \mathrm{SD}$; Values are taken in triplicate

Alphabets with different superscripts shows significant difference at 5\% level of significance; T0: $100 \%$ wheat flour and zero\% GCS. T1: $99 \%$ wheat flour and 1\% GCS. T2: $98 \%$ wheat flour and 2\% GCS. T3: $97 \%$ wheat flour and 3\% GCS. T4: $96 \%$ wheat flour and 4\% GCS. T5: 95\% wheat flour and 5\% GCS 
Microbiological analysis (total bacterial counts, yeast and mold counts and Staphylococcus aureus bacteria counts) of brioche samples was done to determine the effect of adding GCS by different concentrations on the microbiological characteristics of the product.

In general Staphylococcus aureus: not detected in all samples during different storage period at room temperature. However, results regarding total bacterial count showed increasing in the number of bacterial count by increasing the storage period (proportional relation) in control and treatments no 1,2 and 3.

On the other hand treatments No 4 and 5 showed inverse relation, as bacterial count decreased by storage time.

While, in case of yeasts and molds counts, it had the same trend in their counts and significance.

According to obtained results, it is recommended use high concentrations from GCS in brioche (4 and 5\%) as they showed antibacterial and antifungal attitude than the low concentrations (1, 2 and $3 \%)$; the differences was significant $(p<0.05)$. However, sensory evaluation showed unacceptability concerning these concentrations from GCS.

The obtained results were compatible with results obtained by Nothias et al. (2016) as they found that, the investigation of new natural products is considered to be a promising approach to discover new sources of antimicrobial activity. This is particularly important due to the global threat of bacterial resistance to currently used antibiotics, which affect people worldwide.

The results also were agree with, Falana et al. (2014), they reported that, Lepidium sativum had antimicrobial, anti-inflammation, antioxidant and many other therapeutic applications effect. Another study conducted in Egypt showed that L. sativum extract exhibits antimicrobial activity against different gramnegative and gram-positive bacteria (Abo El-Maati et al., 2016). Alqahtani et al. (2018) found that, $L$. sativum seeds showed antimicrobial, antioxidant, and anti-inflammatory properties.

\section{The nutritional value of control and brioche from some macro nutrients}

Table (14) showed increasing in protein and fat percentages by increasing GCS percentages. The covered percentage from RDA ranged from $33.84 \%$ (T1) to $36.42 \%$ (T5) for protein and from $30.62 \%$ (T1) to $34.28 \%$ (T5) for fat. However, the covered percentages from carbohydrate from RDA decreased by increasing the added percentages from GCS it ranged between $(13.38 \%-16.14 \%)$ for $\mathrm{T} 5$ and $\mathrm{T} 1$, respectively. The covered percentage from RDA regarding total calories was ranged from $21.91 \%$ to $22.23 \%$

Table (14): Nutritional value of control and brioche comparing with RDA from some nutrients for children aged 4-8 years old

\begin{tabular}{|c|c|c|c|c|c|c|c|c|}
\hline Treatments & Protein & $\begin{array}{c}\% \\
\text { covered } \\
\text { from } \\
\text { RDA } \\
\end{array}$ & Fat & $\begin{array}{c}\% \\
\text { covered } \\
\text { from } \\
\text { RDA } \\
\end{array}$ & Total CHO & $\begin{array}{c}\% \\
\text { covered } \\
\text { from } \\
\text { RDA } \\
\end{array}$ & $\begin{array}{c}\text { Total } \\
\text { Calories }\end{array}$ & $\begin{array}{c}\% \\
\text { covered } \\
\text { from } \\
\text { RDA } \\
\end{array}$ \\
\hline Control & $12.69 \pm 0.05^{\mathrm{f}}$ & 33.84 & $15.31 \pm 0.44^{\mathrm{c}}$ & 30.62 & $36.33 \pm 0.64^{\mathrm{a}}$ & 16.14 & $331.77 \pm 1.29^{\mathrm{a}}$ & 22.11 \\
\hline $\mathbf{T 1}$ & $12.85 \pm 0.01^{\mathrm{e}}$ & 34.26 & $16.77 \pm 0.67^{\mathrm{ab}}$ & 33.54 & $32.82 \pm 1.01^{\mathrm{b}}$ & 14.58 & $333.49 \pm 2.17^{\mathrm{a}}$ & 22.23 \\
\hline $\mathbf{T 2}$ & $13.09 \pm 0.05^{\mathrm{d}}$ & 34.90 & $16.79 \pm 0.64^{\mathrm{ab}}$ & 33.58 & $32.34 \pm 0.41^{\mathrm{b}}$ & 14.37 & $332.83 \pm 4.65^{\mathrm{a}}$ & 22.18 \\
\hline T3 & $13.26 \pm 0.02^{\mathrm{c}}$ & 35.36 & $17.01 \pm 0.45^{\mathrm{a}}$ & 34.02 & $31.34 \pm 1.01^{\mathrm{c}}$ & 13.92 & $331.58 \pm 1.30^{\mathrm{a}}$ & 22.10 \\
\hline $\mathbf{T 4}$ & $13.45 \pm 0.01^{\mathrm{b}}$ & 35.86 & $17.13 \pm 0.18^{\mathrm{a}}$ & 34.26 & $30.62 \pm 0.39^{c}$ & 13.60 & $330.52 \pm 2.46^{\mathrm{ab}}$ & 22.03 \\
\hline T5 & $13.66 \pm 0.02 \mathrm{a}$ & 36.42 & $17.14 \pm 0.00^{\mathrm{a}}$ & 34.28 & $30.11 \pm 0.15^{\mathrm{c}}$ & 13.38 & $328.68 \pm 0.68^{\mathrm{ab}}$ & 21.91 \\
\hline RDA(g/day) & 37.5 & - & 50 & - & 225 & - & 1500 k.cal. & - \\
\hline
\end{tabular}

Values are mean $\pm \mathrm{SD}$; Values are taken in triplicate

Alphabets with different superscripts shows significant difference at 5\% level of significance; T0: $100 \%$ wheat flour and zero $\%$ GCS. T1: 99\% wheat flour and 1\% GCS. T2: 98\% wheat flour and 2\% GCS. T3: 97\% wheat flour and 3\% GCS. T4: $96 \%$ wheat flour and 4\% GCS. T5: 95\% wheat flour and 5\% GCS

\section{The nutritional value for control and brioche bread from some minerals:}

From Table (15) it could be concluded that, one unit from Brioche (100 g) covered (13.5-20.5\%) from iron daily amount for children aged $4-8$ years old. Also, more than one third (39.48-47.78\%) and (37.91$39.19 \%$ ) from phosphorus and calcium RDA at the same age.
Meanwhile, it covered more than on fourth from daily recommendations of zinc (26.6-34.4\%). In general all samples at different concentrations covered higher percentage from the daily recommendations than control sample and the percentages from these minerals increased ascendingly by increased the GCS powder in the brioche. 
Table (15): Nutritional value of control and brioche bread comparing with RDA from some nutrients for children aged 4-8 years old

\begin{tabular}{|c|c|c|c|c|c|c|c|c|}
\hline Treatments & $\mathrm{Fe}$ & $\begin{array}{c}\% \\
\text { covered } \\
\text { from } \\
\text { RDA } \\
\end{array}$ & Zn & $\begin{array}{c}\% \\
\text { covered } \\
\text { from } \\
\text { RDA } \\
\end{array}$ & $\mathrm{Ca}$ & $\begin{array}{c}\% \\
\text { covered } \\
\text { from } \\
\text { RDA }\end{array}$ & $\mathbf{P}$ & $\begin{array}{c}\% \\
\text { covered } \\
\text { from } \\
\text { RDA } \\
\end{array}$ \\
\hline Control & $1.28 \pm 0.08^{\mathrm{e}}$ & 12.8 & $1.23 \pm 0.01^{\mathrm{e}}$ & 24.6 & $373.11 \pm 0.78^{\mathrm{f}}$ & 37.31 & $184.88 \pm 0.40^{\mathrm{f}}$ & 36.976 \\
\hline $\mathbf{T 1}$ & $1.35 \pm 0.09^{\mathrm{de}}$ & 13.5 & $1.33 \pm 0.02^{\mathrm{d}}$ & 26.6 & $379.07 \pm 1.25^{\mathrm{e}}$ & 37.91 & $197.38 \pm 1.86^{\mathrm{e}}$ & 39.48 \\
\hline $\mathbf{T 2}$ & $1.44 \pm 0.10^{\mathrm{d}}$ & 14.4 & $1.41 \pm 0.01^{\mathrm{c}}$ & 28.2 & $381.92 \pm 0.85^{\mathrm{d}}$ & 38.19 & $204.83 \pm 0.88^{d}$ & 40.97 \\
\hline T3 & $1.64 \pm 0.08^{\mathrm{c}}$ & 16.4 & $1.44 \pm 0.01^{\mathrm{c}}$ & 28.8 & $386.45 \pm 0.83^{c}$ & 38.65 & $210.05 \pm 1.41^{\mathrm{c}}$ & 42.01 \\
\hline T4 & $1.80 \pm 0.08^{\mathrm{b}}$ & 18.0 & $1.49 \pm 0.03^{b}$ & 29.8 & $391.94 \pm 0.92^{\mathrm{a}}$ & 39.19 & $223.35 \pm 1.36^{\mathrm{b}}$ & 44.67 \\
\hline T5 & $2.05 \pm 0.02^{\mathrm{a}}$ & 20.5 & $1.72 \pm 0.09^{\mathrm{a}}$ & 34.4 & $388.68 \pm 2.29^{b}$ & 38.87 & $238.93 \pm 3.27^{\mathrm{a}}$ & 47.78 \\
\hline RDA(mg/day) & 10 & - & 5 & - & 1 & - & 500 & - \\
\hline
\end{tabular}

Values are mean $\pm \mathrm{SD}$; Values are taken in triplicate

Alphabets with different superscripts shows significant difference at 5\% level of significance; T0: $100 \%$ wheat flour and zero $\%$ GCS. T1: 99\% wheat flour and 1\% GCS. T2: $98 \%$ wheat flour and 2\% GCS. T3: $97 \%$ wheat flour and 3\% GCS. T4: $96 \%$ wheat flour and 4\% GCS. T5: $95 \%$ wheat flour and 5\% GCS

The cost of control and prepared brioche bread:

Data in Table (16) illustrated the total cost of brioche and control sample. From this table it could be noticed that, the cost of control and samples were nearly the same, however control sample had the lowest cost meanwhile, T5 had the highest one. The total cost of every treatment was divided into ten as the total dough gave ten brioche units.

Statistical analysis for sensory evaluation in Table (6) revealed that, no significant differences were observed among control and treatments (T1, T2 and T3) in all parameters. However, these differences were significant between control and T4 and T5.

The purchasing intent confirmed the results of sensory evaluation as the significant differences $(\mathrm{p}<0.05)$ were found between control and T4 \& T5 whereas there was no significant differences $(\mathrm{p}>0.05)$ between control and the first three treatments.

Table (16): Cost of control and prepared brioche bread

\begin{tabular}{|c|c|c|c|c|c|c|c|c|c|c|c|c|}
\hline \multirow{3}{*}{ Ingredients } & \multicolumn{12}{|c|}{ Brioche formulation } \\
\hline & \multicolumn{2}{|c|}{ Control } & \multicolumn{2}{|c|}{ T1 } & \multicolumn{2}{|c|}{ T2 } & \multicolumn{2}{|c|}{ T3 } & \multicolumn{2}{|c|}{ T4 } & \multicolumn{2}{|c|}{ T5 } \\
\hline & $\mathbf{g}$ & P.T & $\mathbf{g}$ & P.T & g & P.T & g & P.T & g & P.T & g & P.T \\
\hline Wheat flour & 1000 & 650 & 990 & 643.5 & 980 & 637 & 970 & 629.5 & 960 & 624 & 950 & 618.5 \\
\hline 2Eggs & 116 & 300 & 116 & 300 & 116 & 300 & 116 & 300 & 116 & 300 & 116 & 300 \\
\hline Sugar & 83.11 & 66 & 83.11 & 66 & 83.11 & 66 & 83.11 & 66 & 83.11 & 66 & 83.11 & 66 \\
\hline Butter & 200 & 1400 & 200 & 1400 & 200 & 1400 & 200 & 1400 & 200 & 1400 & 200 & 1400 \\
\hline Dried yeast & 20 & 50 & 20 & 50 & 20 & 50 & 20 & 50 & 20 & 50 & 20 & 50 \\
\hline Milk & 200 & 200 & 200 & 200 & 200 & 200 & 200 & 200 & 200 & 200 & 200 & 200 \\
\hline Vanilla & 2 & 50 & 2 & 50 & 2 & 50 & 2 & 50 & 2 & 50 & 2 & 50 \\
\hline $\begin{array}{l}\text { Baking } \\
\text { powder }\end{array}$ & 4 & 150 & 4 & 150 & 4 & 150 & 4 & 150 & 4 & 150 & 4 & 150 \\
\hline Salt & 5 & 10 & 5 & 10 & 5 & 10 & 5 & 10 & 5 & 10 & 5 & 10 \\
\hline G.C.S & - & - & 10 & 60 & 20 & 120 & 30 & 180 & 40 & 240 & 50 & 300 \\
\hline Cost & - & 2876 & - & 2929.5 & - & 2983 & - & 3035.5 & - & 3090 & - & 3144.5 \\
\hline $\begin{array}{l}\text { Cost for one } \\
\text { unit } \\
\text { of brioche }\end{array}$ & - & 287.6 & - & 292.95 & - & 298.3 & - & 303.55 & - & 309.0 & - & 314.45 \\
\hline $\begin{array}{l}\text { Purchase } \\
\text { intent }\end{array}$ & & $\begin{array}{l}4.14 \pm \\
0.85^{\mathrm{a}}\end{array}$ & & $\begin{array}{l}3.69 \pm \\
0.81^{\mathrm{ab}}\end{array}$ & & $\begin{array}{l}3.80 \pm \\
0.90^{\mathrm{ab}}\end{array}$ & & $\begin{array}{l}3.73 \pm \\
0.97^{\mathrm{ab}}\end{array}$ & & $\begin{array}{l}3.31 \pm \\
0.88^{\mathrm{b}}\end{array}$ & & $\begin{array}{l}2.55 \pm \\
1.40^{\mathrm{c}}\end{array}$ \\
\hline
\end{tabular}

T0: $100 \%$ wheat flour and zero $\%$ GCS. T1: 99\% wheat flour and 1\% GCS. T2: 98\% wheat flour and 2\% GCS. T3: 97\% wheat flour and 3\% GCS. T4: 96\% wheat flour and 4\% GCS. T5: 95\% wheat flour and 5\% GCS. 


\section{CONCLUSION}

The focus of this study was to produce and evaluate of brioche bread by using Egyptian wheat flour extraction $72 \%$ and five concentrations from GCS powder as a functional food. GCS are rich source of proteins, dietary fiber and minerals. It contains phenolic compounds which might be responsible for its strong antioxidant capacity. These results can use easily in the Egyptian Bakery pilot plants to arrive strategic goal of Egyptian government, especially with the low cost of the brioche bread unit.

\section{ACKNOWLEDGMENT}

The authors gratefully acknowledge to Professor Dr. Mohamed Zakaria Sedik, Agriculture Microbiology, Faculty of Agriculture, Cairo University for his active contribution to this research regarding the microbiological part. A lot of thanks to Prof. Dr. Mona A. and Prof. Dr. Hinar A. Seleem Department of Crops Technology Research, Food Technology Research Institute, Agricultural Research Center, Giza, Egypt for their effort provided through this work.

\section{REFERENCES}

AOAC (2012). Official Methods of Analysis of the Association of Official Analytical Chemists, $19^{\text {th }} \mathrm{ed}$, Arligton, Virginia, USA.

AboEl-Maati, F. M., A. S. Mahgoubb, M. S. Labib, A. M. A. Al-Gaby and F. M. Ramadan (2016). Phenolic extracts of clove (Syzygium aromaticum) with novel antioxidant and antibacterial activities. European Journal of Integrative Medicine, 8(4): 494-504.

Alqahtani, F. Y., F. S. Aleanizy, A. Z. Mahmoud, N. N. Farshori, R. Alfaraj, E. S. Al-sheddi and I. A. Alsarra (2018). Chemical composition and antimicrobial, antioxidant, and anti inflammatory activities of Lepidium sativum seed oil. Saudi Journal of Biological Sciences. https://doi.org/10.1016/j.sjbs.2018.05.007.

Altamirano-Fortoul, R. and C. M. Rosell (2011). Physico-chemical changes in breads from bake off technologies during storage. LWTFood Science and Technology, 44(3): 631636.

Aydemir, T. and S. Becerik (2011). Phenolic content and antioxidant activity of different extracts from Ocimum basilicum, Apium graveolens and Lepidium sativum seeds, Food Biochemistry, 35(1): 62-79.

Alvarez-Jubete, L., E. K. Arendt and E. Gallagher (2010). Nutritive value of pseudocereals and their increasing use as functional gluten-free ingredients. Trends in Food Science \& Technology, 21(2): 106-113.

And, M. A. and I. Alli (1988). Composition and properties of seeds and pods of the tree legume Prosopis juliflora (DC). Journal of the Science of Food and Agriculture, 44(2): 99-110.

American Public Health Association Methods (APHA) (1994). Standard methods for the examination of dairy products, $16^{\text {th }}$ Ed., American Public Health Association, Washington, USA.

Belderok, B., J. Mesdag and D. A. Donner (2000). Bread making quality of wheat: A century of breeding in Europe. Kluwer Academic Publisher: Dordrecht, the Netherlands, pp. 3031.

Catteral, P. (1995). Flour milling. In: Technology of Bread making. Second Edition (SP Cauvain and LS Young eds), Aspen Publishers Inc. Gaithersburg. pp. 296-329.

Doke, S. and M. Guha (2014). Garden cress (Lepidium sativum L.) seed - An Important Medicinal Source: A Review. Scholars Research Library. Journal of Natural Product and Plant Resources, 4(1): 69-80.

Elemo, G. N., A. A. Osibanjo, O. P. Ibidapo, A. O. Ogunji, W. B. Asiru, T. Zakari and O. G. Olabanji (2017). Rheological characteristics and baking quality of flours from Nigerian grown wheat. African Journal of Food Science, 11(12): 376-382.

Elizabeth, K. G. G. and R. H. Poojara (2014). Organoleptic attributes of garden cress seed incorporated snacks suitable for adolescents. International Journal of Food Sciences and Nutrition, 3(6): 126-129.

Falana, H., W. Nofal and H. Nakhleh (2014). A Review Article Lepidium sativum (Garden cress).

Food Fortification Initiative (2019). http://www.ffinetwork.org/ visited on 20/1/2019.

Gokavi, S. S., N. G. Malleshi and M. Guo (2004). Chemical composition of garden cress (Lepidium sativum) seeds and its fractions and use of bran as a functional ingredient. Plant Foods for Human Nutrition, 59(3): 105-111.

Gomez, M., F. Ronda, C. A. Blanco, P. A. Caballero and A. Apesteguia (2003). Effect of dietary fiber on dough rheology and bread quality. European Food research and technology, 216(1): 51-56.

Hatcher, D. W., G. G. Bellido and M. J. Anderson (2009). Flour particle size, starch damage, and alkali reagent: impact on uni-axial stress relaxation parameters of yellow alkaline noodles. Cereal Chemistry, 86(3): 361-368.

Hozova, B., L. Kukurova, R. Turicova and L. Dodok (2002). Sensory quality of stored croissanttype bakery products. Czech journal of food science, 20(3): 105-112.

ICMR (2010). Nutrient requirements and recommended dietary allowance for Indians. A Report of the Expert Group of the Indian Council of Medical Research, New Delhi.

Kasabe, P. J., P. N. Patil, D. D. Kamble and P. B. Dandge (2012). Nutritional, elemental analysis and antioxidant activity of garden cress (Lepidium sativum L.) seeds. International Journal of Pharmacy and Pharmaceutical Sciences, 4(3): 392-395. 
Kerolles, S. Y. (1986). The pectic substances. Intercience Publishers, Inc., New Yrok.

Kitterman, J. S. and G. L. Rubenthaler (1971). Assessing the quality of early generation wheat selection with the micro AWRC test. Cereal Science Today, 16(9): 313-316.

Massoud, R., K. Khosravi-Darani, F. Nakhsaz and L. Varga (2016). Evaluation of physicochemical, microbiological and sensory properties of croissants fortified with Arthrospira platensis (Spirulina). Czech Journal of Food Sciences, 34(4): 350-355.

Nathiya, M. and N. Vigasini (2014). Formulations of cereal based nutricookies prepared incorporating garden cress seeds (Lepidium sativum) - a protein and iron rich snack. International Journal of Scientific Research, 3(2): 225-226.

Nothias, L. F., R. Knight and P. C. Dorrestein (2016). Antibiotic discovery is a walk in the park. Proceedings of the National Academy of Sciences, 113(51): 14477-14479.

Ozturk, S., B. Aslim and Z. Suludere (2009). Evaluation of chromium (VI) removal behaviour by two isolates of Synechocystis sp. in terms of exopolysaccharide (EPS) production and monomer composition. Bioresource Technology, 100(23): 5588-5593.

Patil, D. D., A. Lal and V. D. Nandkule (2015). Development and quality evaluation of garden cress seed biscuits. International Journal of Science, Engineering and Technology, 3(3): 770-774

Pertuzatti, P. B., S. M. R. Esteves, J. E. Alves, L. C. Lima and J. E. Borges (2015). Sensory evaluation of bakery and confectionery products prepared through semi-industrial and artisanal processes. American Journal of Food Science and Technology, 3(4A): 32-36.

Rasper, V. F. and C. E. Walker (2000). Quality evaluation of cereals and cereal products. In: Handbook of Cereal Science and Technology (edited by K. Kulp and J.G. Ponte). Pp. 505537. New York: Marcel Dekker.

Rosell, C. M. (2009). Trends in bread making: Low and subzero temperatures. In: 412 Innovation in Food Engineering: New Techniques and Products. Ed M.L. Passos, 413 C.L. Ribeiro. Taylor and Francis, CRC Press. Pp 59-79.

Sabanis, D. and C. Tzia (2009). Effect of rice, corn and soy flour addition on characteristics of bread produced from different wheat cultivars. Food Bioprocess Technology, 2(1): 68-79.

Shail, D. M., N. Kumar and L. N. Gupta (2016). Nutritional importance of Lepidium sativum
L.(Garden cress/Chandrashoor): A Review. International Journal of Pharmacy and Analytical Research, 5(1): 152-160.

Shapiro, S. S. and M. B. Wilk (1965). An Analysis of variance test for normality (complete samples), Biometrika, 52(3/4): 591-611.

Shewry, P. R. and S. J. Hey (2015). The contribution of wheat to human diet and health. Food and Energy Security, 4(3): 178-202.

Singh, C. S. and V. K. Paswan (2017). The Potential of Garden Cress (Lepidium sativum L.) Seeds for Development of Functional Foods. In Advances in Seed Biology. In TechOpen. http://dx.doi.org/10.5772/ intechopen.70355.

Smith, N and Y. Jianmei (2015). Nutritional and sensory quality of bread containing different quantities of grape pomace from different grape cultivars. EC Nutrition, 2(1): 291-301.

Snedecor, G. W. and W. G. Cochran (1994). Statistical Methods. $9^{\text {th }}$ Ed., Iowa State Univ. Press, Ames, Iowa, USA.

Sofowora, A. (1982). Medicinal plants and traditional medicine in Africa. John Wiley and sons LTD.

SPSS Statistics 17.0 (2008). SPSS for Windows. SPSS Inc. 2008.

Sramkovaa, Z., E. Gregovab and E. Sturdika (2009). Chemical composition and nutritional quality of wheat grain. Acta Chimica Slovaca, 2(1): 115-138.

Tacer-Caba, Z., D. Nilufer-Erdil and Y. Ai (2015). Chemical composition of cereals and their products. Handbook of Food Chemistry, 1-23. DOI 10.1007/978-3-642-41609-5_33-1\# Springer-Verlag Berlin Heidelberg

Xie, F., E. Floyd, S. Dowell and S. X. Sun (2004). Using visible and near-Infrared reflectance spectroscopy and differential scanning colorimetry to study starch, protein and temperature effects on bread staling. Cereal Chemistry, 81(2): 249-254.

Yadav, Y. C., N. D. Srivastava, V. Saini, A. K. Seth, T. K. Ghelani, A. Malik and S. Kumar (2011). In-vitro antioxidant activity of aethanolic extracts of Lepidium sativum L. seeds. Pharma Science Monitor, 2(3): 244-253.

Yamazaki, W. T. (1953). An alkaline water retention capacity test for the evaluation of cookie baking potentialities of soft winter wheat flours. Cereal Chemistry, 30: 242-246.

Zia-Ul-Haq, M., S. Ahmad, L. Calani, T. Mazzeo, D. Del Rio, N. Pellegrini and V. De Feo (2012). Compositional study and antioxidant potential of Ipomoea hederacea Jacq. and Lepidium sativum L. seeds. Molecules, 17(9): 10306-21. 


\section{التقييم التظذوى لخبز البريوش المصنوع من القمح المصري والمدعم بمسحوق بذور حب الرشاد كغذاء وظيفي

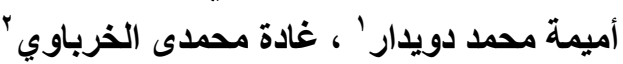

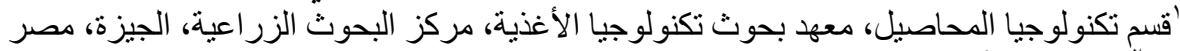

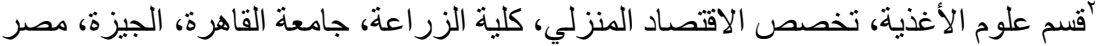

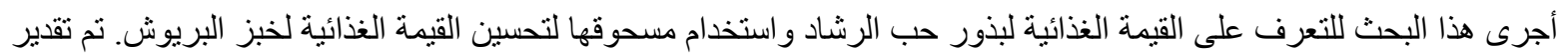

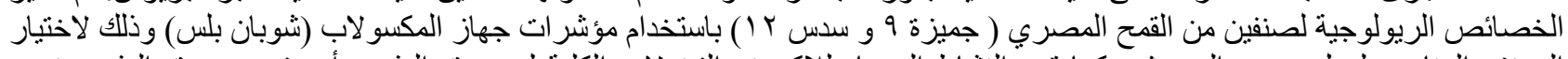

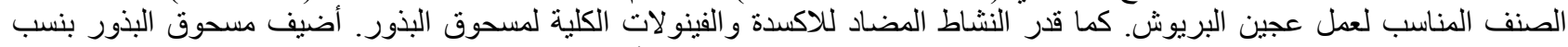

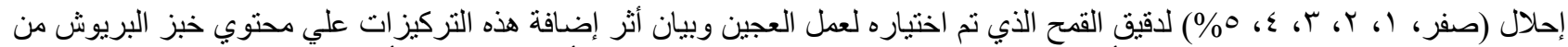

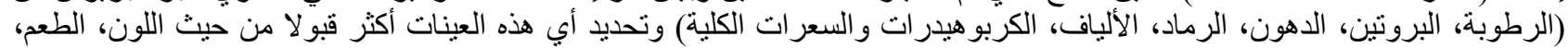

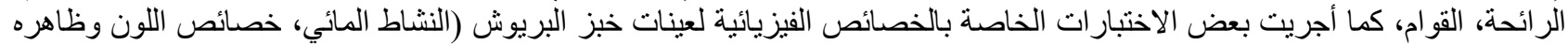

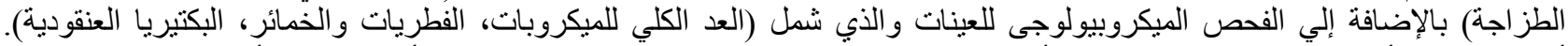

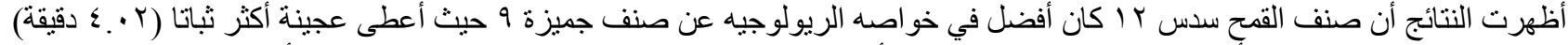

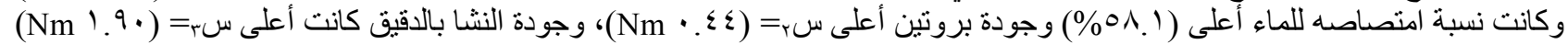

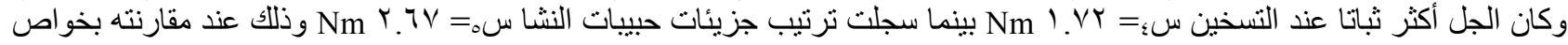

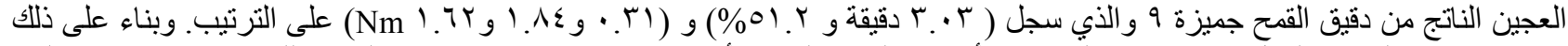

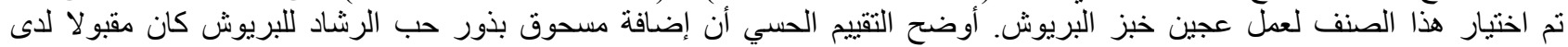

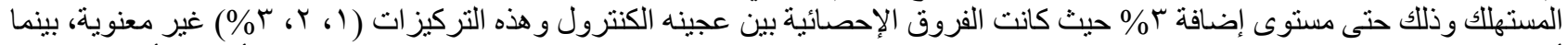

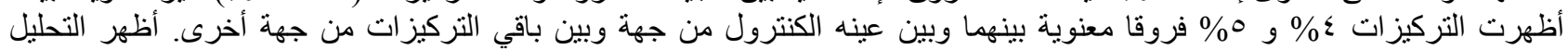

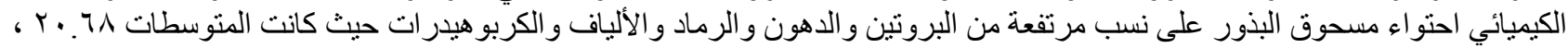

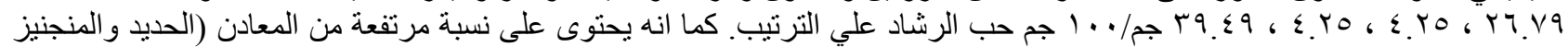

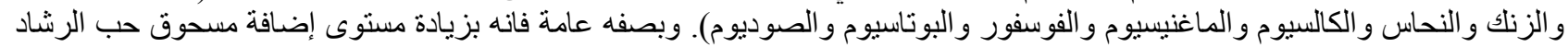

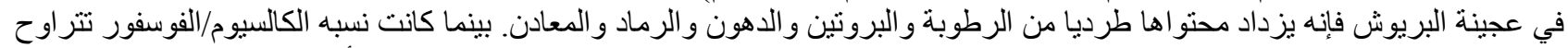

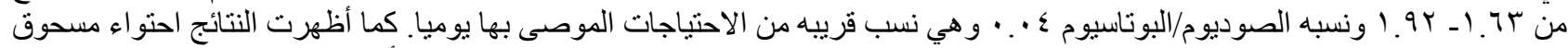

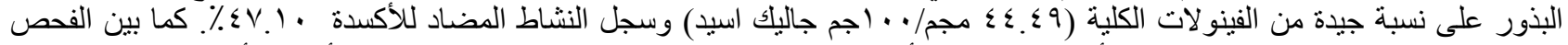

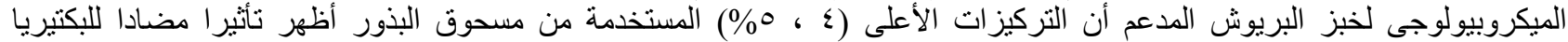

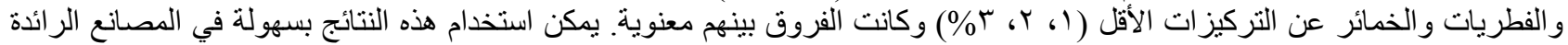
في مجال الخبز المصري للوصول إلى الهذف الاستر اتيجي للحكومة المصرية خاصة، مع انخفاض تكلفة وحدة خبز البريوش كغذاء وظيفيى. 